\title{
Still Waiting for the Barbarians
}

\section{HOWARD MCNAUGHTON}

UNIVERSITY OF CANTERBURY

\section{Tzvetan Todorov}

The Fear of Barbarians: Beyond the Clash of Civilisations

Polity Press, Cambridge, 2010

ISBN 9780745647104

RRP $£ 15.99$ (pb)

More than a century separates Tzvetan Todorov's new book from Constantine Cavafy's classic poem 'Waiting for the Barbarians',1 a work which uncannily anticipates it in several important respects, and which has recently been seen as prophetic of the War on Terror. In that intervening century, our lexicon has swollen to accommodate concepts like 'ethnic cleansing', 'Ubermensch' and 'Holocaust', while cultural hybridity, a concept scarcely known in Cavafy's time, has claimed a new urgency among many cultural and political commentators.

Todorov has left little doubt about his own proclivities since his early work on Bakhtin, but there has been a noticeable immediacy of focus in his work since his masterful On Human Diversity (1993). Like his good friend and mentor Edward Said, Todorov is exercised by the success of Samuel Huntington's The Clash of Civilizations and the Remaking of World Order (1996) and the populist obsession with 'Muslim Rage' and 'Islamic contagion'. Before reaching that specific focus, however, Todorov 
is careful to establish a number of preliminaries, in a chapter on 'collective identities', which is primarily concerned with 'the plurality of cultures': 'if cultural identity never changed, France would never have become Christian, to begin with, and then secular subsequently ... Before it influenced other cultures in the world, European culture had already absorbed Egyptian, Mesopotamian, Persian, Indian, Islamic and Chinese influences.' (56) If there is little in this section that was not established in On Human Diversity, the scope here goes well beyond the Francophone focus of the earlier book, although even this has its obvious limits: he is severe in his condemnation of Huntington's elision of 'culture' and 'civilisation', but his own usage could be more precise.

Todorov's critique of Huntington's 'shapeless' book is sharp and strategic. As early as Huntington's 1993 article (the prototype of the book), he was describing the contact points between civilisations as 'fault lines', suggesting a quasi-seismic natural barrier, and it is this kind of mental entrenchment that Todorov is primarily concerned to demolish, especially as Huntington compartmentalises 'challenger civilisations', 'swing civilisations', 'torn countries' and a curious category which he terms 'cleft countries' (with an implication of hybridity). For Todorov, however, this is more than just what Said termed a 'clash of ignorance'; he expresses surprise at the paradoxical proliferation of walls in the age of globalisation, where goods and capital are increasingly in free circulation, along with information and destruction. 'The cloud from Chernobyl did not stop at the Rhine.' (185) The circulation of people, however, is another matter.

It is not difficult to guess where the People's Republic of China fits in Huntington's scheme. Even in Hume's time, Todorov reminds us, China was categorised by its absence of 'inner plurality': 'China is one vast empire, speaking one language, governed by one law, and sympathising in the same manners'. (176) Even Khubilai Khan had doubts about whether a political unit on this scale was sustainable, but one has only to compare perceptions of China by Todorov's Parisian contemporaries such as Godard, Debord and Kristeva to see the astonishing survival of such stereotypes. When Kristeva went to Beijing in 1974, two years before the Tangshan earthquake, the walls of China seemed as impenetrable as ever; the earthquake killed at least two hundred and fifty thousand people, but Mao, who was himself terminally hospitalised at the time, refused external aid such as the 
International Red Cross. Yet less than two years later the introduction of the 'four modernisations', including the 'Opening Up of China', the rejigging of Chinese socialism, and the one child policy, presented a spectacular reversal of the situation Hume had sketched. Rather than affirming an absence of plurality, in many cases it is legitimised: the one child law, for example, specifically excludes ethnic minorities and various other groups which are seen to need protection. In these terms, it would be difficult to argue that the cultural identity of China differs from the inner plurality' which Todorov finds fundamental to European culture.

The plurality argument, if not exactly groundbreaking, certainly is fully developed in this book, which concludes with the assertion that 'Every society ... is pluricultural' and an emphasis on 'good management of this growing plurality'. (198) There is, however, a latent problem here, in that in his introduction Todorov approvingly cites his Parisian colleague (and Holocaust survivor descendant) Dominique Moisi's The Geopolitics of Emotion: How Cultures of Fear, Humiliation and Hope Are Reshaping the World (2009). Although he does not directly refer to Moisi again, a modified version of his thesis is used throughout Todorov's book: the introduction is entitled 'between fear and resentment' and the conclusion, though entitled 'Beyond Manicheism', states that for centuries 'the current "countries of fear" have dominated the current "countries of resentment"'. (196) From there he moves to a cogent critique of 'the reductive vision' which turns the Muslim population-with its plurality of components-into 'Islam', which in turn is reduced to 'Islamism'. (197) But while deploring this vision, Todorov is himself endorsing Moisi's essentialising typology, which sees humiliation as pervasive in the Islamic world, with fear becoming dominant in the West, particularly since 9/11.

Although the primary meaning is clear, an important ambiguity is latent in Todorov's title: La peur des barbares raises the question, Who is doing the fearing? This reciprocity is suggested even in Cavafy's poem, and becomes almost axiomatic to Todorov, who argues consistently that barbarism consists in 'not recognizing the humanity of others', (195) that 'The fear of barbarians is what risks making us barbarian' (6) and that 'no people, no individual, is immune to the possibility of carrying out barbaric acts', (21) an argument reinforced by analysis of the West's current practices of torture. At the same time, however, Todorov asserts that the notion of "barbarian" [is] found in Europe but not in other great cultures such as 
China'. (178) Elsewhere, he acknowledges that the South American 'Indians' considered the Spanish barbarians, also for language reasons.

In Todorov's geopolitics, China is propelled by appetite and resentment. It is difficult however to use this to account for Chinese attitudes towards the Mongol/Tatar invasions. Marco Polo observed that Khubilai Khan was the first of his line to raise himself above the 'natural and systematic barbarianism' of the Mongols, ${ }^{2}$ and quotes Chinese reports of Mongol attitudes to various barbarian peoples which they had themselves conquered. Among the most famous Yuan dynasty travel narratives is Wang Dayuan's Description of the Barbarians of the Isles, which is thought to include an account of the northern coast of Australia and its inhabitants in the early fourteenth century. ${ }^{3}$ Perhaps the most interesting case of all-especially in the interpretation of 'Muslim Rage' - is that of Tamerlane, who, though of Mongol stock, was also a Muslim controlling what was then 'the global

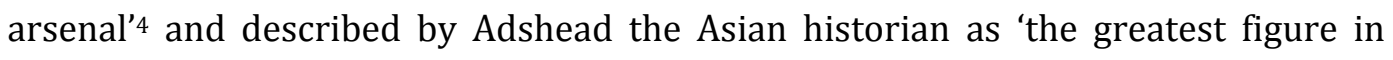
Central Asian political history'. Adshead continues, 'Illiterate but cultivated, the barbarian with a portable bath, porcelain tea services and a taste for architecture, Tamerlane was a more deliberate conqueror than Chinggis', and was on the verge of invading China at the time of his death. ${ }^{5}$ Even in the nineteenth century, official internal Chinese correspondence regularly refers to the 'English [as well as American and Portuguese] Barbarians' within the context of the Opium Wars; the 'American barbarian' was of a different order from the English, who at least sometimes knew some Mandarin.

Todorov readily admits that 'a political entity needs frontiers', although he also suggests that today it is preferable to think of these not as walls but as thresholds. If it is unclear how this is to be reconciled with China erecting the most substantial wall in the world without having a notion of barbarians-and without it even being noticed by Marco Polo-the case of Europe is even more problematic. In his afterword, written after the publication of the French original, Todorov is mainly concerned with current American policy and practice in Afghanistan. But in the final chapter of the French edition he turns to the question of a European identity, mainly within the context of the European Economic Community (EEC)/European Union (EU). It is clear that Todorov was finishing his book at a point when Turkey was again lobbying hard for membership of the EU, a case which again stretches the 
notion of the frontiers of Europe and which leads him to reflect on whether strategic interest might also be used as a criterion for admission. But since that was completed, we have seen massive bail-outs of Greece and more recently of Ireland in the form of EU-IMF loans, and in some quarters an argument for exclusion, for more walls.

For all its ambitious scope, this book is inevitably selective in its detail, and all readers will spot parts of the argument which need further explication, especially the ending, which tapers off into an indeterminate reflection on the bid from Turkey and possible future admissions (Belarus, possibly; Russia-forget it!). It is however also clear that Todorov sees it as a commentary on a situation in process, and no claim is made to suggest that this is the last word on the subject. That having been said, every library should have this book, which has already appeared in an Arabic translation, and which ranks beside Nicholas Mirzoeff's Watching Babylon as one of the most provocative cultural analyses of the current situation.

Howard McNaughton is Professor of English and Cultural Studies at the University of Canterbury. His latest book is The Cultural Reinvention of Everyday Life (in Mandarin, 2010).

\footnotetext{
-Notes

${ }^{1}$ C.P. Cavafy, Collected Poems, trans. Daniel Mendelsohn, Alfred A. Knopf, New York, 2009, p. 192.

2 Marco Polo, The Travels of Marco Polo: The Complete Yule-Cordier Edition, Dover, Mineola, NY, 1920, p. 1104.

3 Wang Dayuan, Daoyi zhilüe (Description of the Barbarians of the Isles), Zhonghua shuju, Beijing, 1981. ${ }^{4}$ S.A.M. Adshead, Central Asia in World History, St Martin's Press, New York, 1993; this is the title of the fifth chapter.
}

${ }^{5}$ S.A.M. Adshead, T'ang China: The Rise of the East in World History, Palgrave Macmillan, Basingstoke and New York, 2004, pp. 175-6. 